\title{
Condylar form alteration on skeletal class II patients that underwent orthognathic surgery: An overview of systematic reviews
}

\author{
Inês Francisco ${ }^{1}$, Adriana Guimarães ${ }^{1}$, Margarida Lopes ${ }^{2}$, António Lucas ${ }^{2}$, Francisco Caramelo ${ }^{3}$, Francisco \\ Vale $^{4}$ \\ ${ }^{1}$ DDS, MSc. Assistant Professor, Institute of Orthodontics, Faculty of Medicine, University of Coimbra, Portugal \\ ${ }^{2}$ DDS, MSc. Orthodontic Postgraduate, Institute of Orthodontics, Faculty of Medicine, University of Coimbra, Portugal \\ ${ }^{3} \mathrm{PhD}$. Professor, Institute of Clinical and Biomedical Research of Coimbra (iCBR), Faculty of Medicine of the University of \\ Coimbra, Portugal \\ ${ }^{4}$ DDS, MSc. PhD. Program Director and Head of Department, Institute of Orthodontics, Faculty of Medicine, University of Coim- \\ bra, Portugal
}

Correspondence:

Faculty of Medicine, University of Coimbra

Avenida Bissaya Barreto, Blocos de Celas

3000-075 Coimbra, Portugal

franciscofvale@gmail.com

Francisco I, Guimarães A, Lopes M, Lucas A, Caramelo F, Vale F. Condylar form alteration on skeletal class II patients that underwent orthognathic surgery: An overview of systematic reviews. J Clin Exp Dent. 2020;12(7):e695-703.

Received: 18/02/2020 Accepted: 13/04/2020

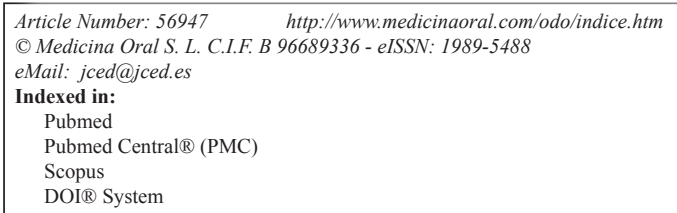

\begin{abstract}
Background: Bilateral sagittal split osteotomy (BSSO) is commonly considered as the surgical technique of election for the treatment of skeletal class II with mandibular hypoplasia. After orthognathic surgery, condylar resorption can occur as a surgical relapse, which may affect the temporomandibular joint. Objective: This study aimed to summarise published systematic review that assess if orthognathic surgery with mandibular advancement performed on skeletal class II patients results in condylar form alteration.

Material and Methods: A literature search was performed using the electronic databases PubMed, Web of Science, Cochrane Library, Embase along with several sources of grey literature. Selection Criteria: Inclusion criteria were systematic reviews published until December 2019, of skeletal class II patients aged more than 18 years old that underwent BSSO with mandibular advancement surgery. Data collection: The electronic search identified 37 publications. Four publications fulfilled the inclusion criteria and were included in this meta-analysis. Qualitative assessment of the selected studies was performed using the Assessment of Multiple Systematic Reviews - AMSTAR 2 checklist.

Results: Four systematic reviews were included in this review. Despite its low incidence all studies reported condylar resorption. However, there were methodological limitations in all assessed articles.

Conclusions: The alteration of the condylar form may be a consequence of BSSO with mandibular advancement surgery. Additional high quality prospective research assisted by 3D-imaging technology is needed to allow more definite conclusions.
\end{abstract}

Key words: Evidence-based orthodontics, TMJ, Class II, mandibular advancement, malocclusion, Angle class II. 


\section{Introduction}

Condylar form alteration is a common factor associate with development of skeletal relapse (1). This is defined as an irreversible progressive alteration of shape and volume of the mandibular condyles following a bilateral sagittal split osteotomy (BSSO) after orthognathic surgery. The alteration of the condylar form alteration is rare but it is a well-known clinical situation that usually affects the temporomandibular joint (TMJ) (2).

BSSO is commonly considered as the surgical technique of election for the treatment of skeletal class II with mandibular hypoplasia (3). The mandibular advancement tends to cause an anterior position of the condyle within the mandibular fossa, which in turn forces the entire condyle/disc complex to follow the same movement during one period of time. In addition, this new anterior mandibular pose generally requires new accommodation of the surrounding soft tissue with major implications in muscle fibres. It seems clear, that this type of therapy frequently leads to a number of changes in the stomatognathic system (4).

The natural adaptive capacity of the TMJs when exceeded may originate in condylar remodeling (5). However, despite these various changes, little is known about the true effect of protrusion as a predisposing, initiating or perpetuating agent of temporomandibular disorders (TMD). -Objective

The aim of this systematic review with meta-analysis is to answer the following clinical question according to the PICO model (P, population; I, intervention; $\mathrm{C}$, comparative intervention; $\mathrm{O}$, outcome):

"Does mandibular advancement with sagittal split osteotomy on skeletal class II patients result in temporomandibular disorders determined by condylar form alteration?"

\section{Material and Methods}

This Systematic Review (SR) was based on the guidelines of the PRISMA Statement for reports SRs and meta-analysis of studies evaluating healthcare interventions. We registered it on International Prospective Register of Systematic Reviews (PROSPERO): (CRD 42017080676).

The authors noticed that systematic reviews on this field were already available. Thus, we preferred to carry out a review of existing published systematic reviews. This methodology is becoming usual on literature because permits summarize the extensive scientific knowledge on widely explored research topics, so we opted to include only systematic reviews to perform a meta-analysis.

Selection criteria

1. Study Design: Studies included were systematic reviews.

2. Population: Skeletal class II patients that underwent orthognathic surgery with mandibular advancement.
3. Search Strategy: A literature search was performed in electronic bibliographic databases (PubMed, Web of Science, Cochrane Library, Embase), along with several sources of grey literature.

The search was conducted in December 2019, using the following keywords:

- PubMed: "Malocclusion, Angle Class II"[Mesh] AND ("Mandibular Advancement"[Mesh] OR "Osteotomy, Sagittal Split Ramus”[Mesh]) AND “Condylar Resorption"[All Fields]

- Cochrane Library and Web of Science: (malocclusion, Angle class II OR mandibular advancement) AND (osteotomy, sagittal split ramus) AND (condylar resorption). - EMBASE: (mandibular advancement surgery OR sagittal split ramus osteotomy) AND (temporomandibular disorders).

The inclusion criteria were systematic reviews and Meta-analysis; performed on adults aged more than 18 years old who underwent BSSO with mandibular advancement surgery.

We excluded case reports and case series, randomized and non-randomized controlled trials, cohort studies, editorials, opinions and studies not specifying the parameters of interest, and publications not fulfilling the inclusion criteria.

The selected publications were imported to EndNote software (Thomson Reuters Software; http://endnote. com; 2016), and the duplicates were removed.

Selection of Studies

Two review authors (IF, AG) performed the study selection independently and in duplicated. They were not blinded to the identity of the authors or their reported results. Selection of the eligible studies was based on screening of the titles and abstracts. Two reviewers (AL, ML) analyzed the full texts of those that met the eligibility criteria. Any disagreement was resolved by consulting a third reviewer (FV). Reviewers kept a record of all the decisions on study identification.

Qualitative Assessment of Included Studies

The qualitative assessment of the selected studies was performed using the Assessment of Multiple Systematic Reviews (AMSTAR 2) (https://amstar.ca/mascripts/ Calc_Checklist.php) checklists. AMSTAR checklists contain several questions directed only to systematic reviews under evaluation.

Statistical Analysis

The sample size, number of subjects and quantitative assessment of the condylar form alteration was collected from the articles of each systematic review included in this overview. Based on these values a meta-analysis was conducted to determine the incidence of condylar form alteration after BSSO surgery. The analysis was carried out resorting to the $\mathrm{R}$ statistical platform, in particular to the "metafor" package (6). The heterogeneity of the studies was assessed with I2 coefficient and the Q test. 


\section{Results}

The electronic searches identified 37 publications. Two review authors examined titles and abstracts of 9 articles were considered potentially relevant (Fig. 1). Full reports were obtained and assessed independently by the review authors. After reading these articles, 5 were excluded by applying the inclusion and exclusion criteria. The main reasons for those items excluded are discriminated in Table 1 (2,7-11).

The 4 selected studies were subjected to qualitative assessment by two review authors (IF, AG). Disagree- ments were resolved through mediation with a third review (FV). Two studies were considered as low quality of evidence $(3,12)$ and the other two were judged as moderate quality of evidence $(4,11)$, using the AMSTAR 2 checklists.

The detailed results of the accepted publications are explained in Tables 2,3,3 cont. $(3,4,11,12)$. The correlation between condylar remodeling and orthognathic surgery are represented in Table $4(3,4,11,12)$.

The selected papers show some degree of heterogeneity $(\mathrm{I} 2=55.85 \% ; \mathrm{Q}(3)=6.788 ; p=0.0791)$ and for that
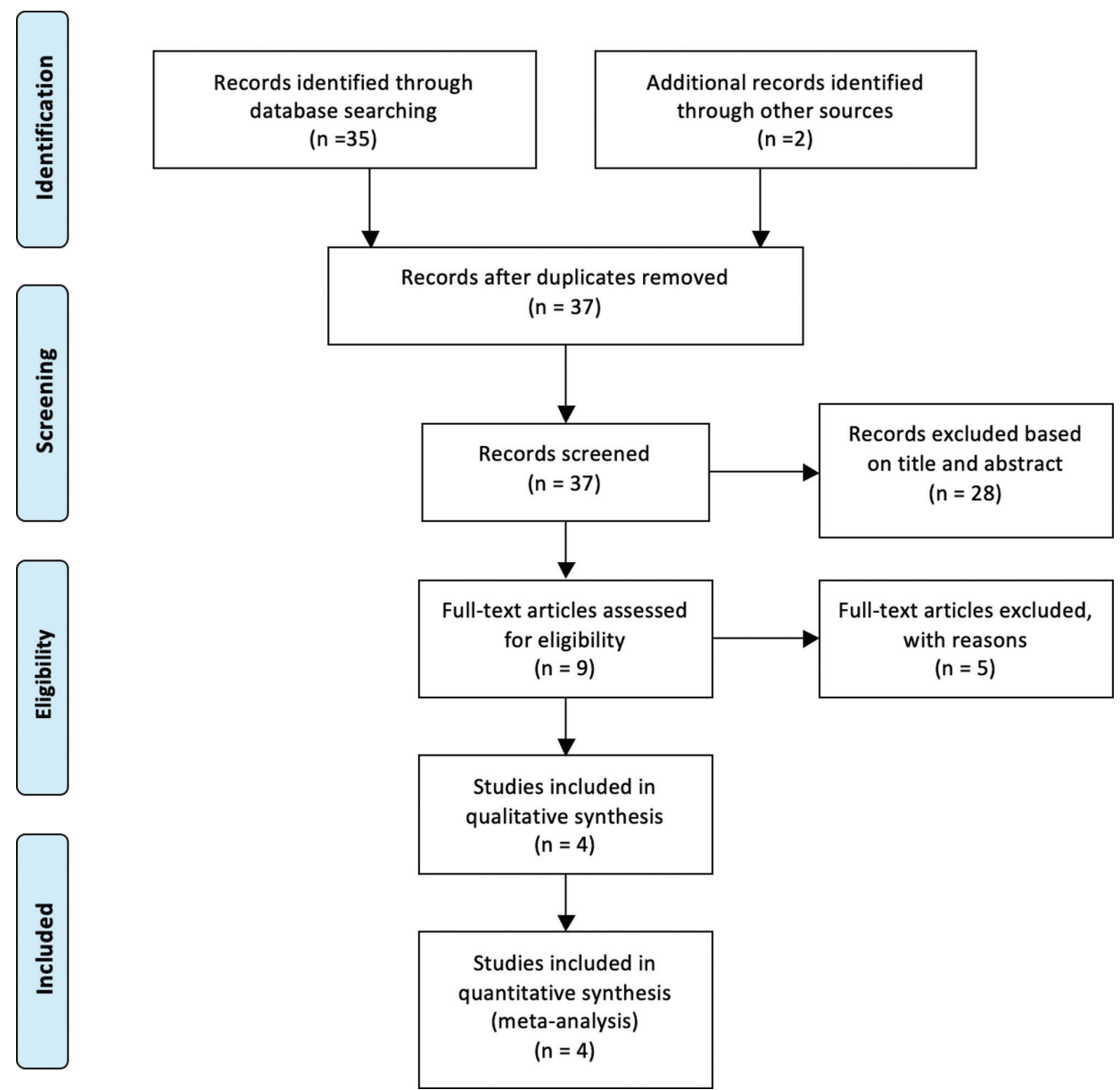

Fig. 1: Flow diagram of literature search and screening process.

Table 1: Reasons for studies exclusion.

\begin{tabular}{|l|c|}
\hline Potencially relevant studies & Main causes for non-selection \\
\hline Hwang $2000(7)$ & Not a systematic review study \\
\hline Hwang 2000 (8) & Not a systematic review study \\
\hline Eggensperger 2006 (9) & Cohort study \\
\hline Ow 2010 (10) & RCT study \\
\hline Catherine 2016 (2) & Not refer the type of surgery \\
\hline
\end{tabular}


Table 2: Characteristics of included studies.

\begin{tabular}{|c|c|c|c|c|c|c|c|c|}
\hline $\begin{array}{c}\text { Author } \\
\text { year }\end{array}$ & Title & $\begin{array}{l}\text { Study } \\
\text { Design }\end{array}$ & Databases & Participants & Interventions & $\begin{array}{c}\text { Observation } \\
\text { period }\end{array}$ & Outcomes & $\begin{array}{c}\text { Diagnostic } \\
\text { Method }\end{array}$ \\
\hline $\begin{array}{l}\text { Bermell- } \\
\text { Baviera et } \\
\text { al., (2016) } \\
\quad \text { (4) }\end{array}$ & $\begin{array}{l}\text { Effects of } \\
\text { mandibular } \\
\text { advancement } \\
\text { surgery on the } \\
\text { temporomandibul } \\
\text { ar joint and } \\
\text { muscular and } \\
\text { articular adaptive } \\
\text { changes-a } \\
\text { systematic review }\end{array}$ & $\begin{array}{c}\text { Systematic } \\
\text { Review }\end{array}$ & $\begin{array}{l}\text { PubMed, Scopus, } \\
\text { Embase and } \\
\text { Cochrane Library }\end{array}$ & $\begin{array}{l}\text { All articles that } \\
\text { investigated } \\
\text { adaptation and } \\
\text { muscular and } \\
\text { anatomical } \\
\text { changes in the } \\
\text { TMJ following } \\
\text { mandibular } \\
\text { advancement } \\
\text { surgery. } \\
\text { (22 articles) }\end{array}$ & BSSO & $\begin{array}{l}\text { All observation } \\
\text { periods were } \\
\text { accepted }\end{array}$ & $\begin{array}{c}\text { Articular } \\
\text { changes, } \\
\text { CR, } \\
\text { Subjective } \\
\text { and clinical } \\
\text { symptoms } \\
\text { of } \\
\text { temporoma } \\
\text { ndibular } \\
\text { dysfunction } \\
\text { and } \\
\text { muscular } \\
\text { adaptation }\end{array}$ & $\begin{array}{c}\text { Different } \\
\text { methods were } \\
\text { implemented. } \\
\text { CBCT and } \\
\text { CT scans } \\
\text { were used but } \\
\text { mostly used } \\
\text { 2-dimentional } \\
\text { imaging } \\
\text { techniques, } \\
\text { such as lateral } \\
\text { teleradiology }\end{array}$ \\
\hline $\begin{array}{l}\text { Mousoulea } \\
\text { et al., } \\
\text { (2016) (3) }\end{array}$ & $\begin{array}{c}\text { Condylar } \\
\text { resorption in } \\
\text { orthognathic } \\
\text { patients after } \\
\text { mandibular } \\
\text { bilateral sagittal } \\
\text { split osteotomy: a } \\
\text { systematic review }\end{array}$ & $\begin{array}{c}\text { Systematic } \\
\text { Review }\end{array}$ & $\begin{array}{l}\text { MEDLINE (via } \\
\text { Ovid and } \\
\text { PubMed, } \\
\text { Supplementary } \\
\text { Data, from 1946 } \\
\text { to 29 November } \\
\text { 2015), EMBASE } \\
\text { (via Ovid), the } \\
\text { Cochrane Oral } \\
\text { Health Group's } \\
\text { Trials Register, } \\
\text { and CENTRAL. } \\
\text { Unpublished } \\
\text { literature was } \\
\text { searched on } \\
\text { ClinicalTrials.gov } \\
\text {,the National } \\
\text { Research } \\
\text { Register, and Pro- } \\
\text { Quest } \\
\text { Dissertation } \\
\text { Abstracts and } \\
\text { Thesis database }\end{array}$ & $\begin{array}{l}\text { Adults of any } \\
\text { age that } \\
\text { underwent a } \\
\text { BSSO for } \\
\text { shifting of the } \\
\text { mandible. } \\
\text { (14 articles) }\end{array}$ & $\begin{array}{l}\text { BSSO alone, or } \\
\text { in conjunction } \\
\text { with other } \\
\text { surgical } \\
\text { procedures }\end{array}$ & $\begin{array}{l}\text { All observation } \\
\text { periods were } \\
\text { accepted }\end{array}$ & $\mathrm{CR}$ & $\begin{array}{c}\text { Different } \\
\text { methods were } \\
\text { implemented. } \\
\text { CBCT scans } \\
\text { were used but } \\
\text { mostly used } \\
\text { 2-dimentional } \\
\text { imaging } \\
\text { techniques, } \\
\text { such as } \\
\text { panoramic } \\
\text { radiography, } \\
\text { lateral } \\
\text { teleradiology } \\
\text { and } \\
\text { tomography }\end{array}$ \\
\hline $\begin{array}{l}\text { te Veldhuis } \\
\text { et al., } \\
\text { (2017) (11) }\end{array}$ & $\begin{array}{l}\text { The effect of } \\
\text { orthognathic } \\
\text { surgery on the } \\
\text { temporomandibul } \\
\text { ar joint and oral } \\
\text { function: a } \\
\text { systematic review }\end{array}$ & $\begin{array}{c}\text { Systematic } \\
\text { Review }\end{array}$ & $\begin{array}{c}\text { Embase, } \\
\text { MEDLINE Ovid, } \\
\text { Cochrane Central } \\
\text { Register of Con- } \\
\text { trolled Trials, } \\
\text { Web of Science, } \\
\text { PubMed (the } \\
\text { subset as supplied } \\
\text { by publishers), } \\
\text { CINAHL } \\
\text { (EBSCOhost), } \\
\text { and Google } \\
\text { Scholar }\end{array}$ & $\begin{array}{l}\text { Adults of any } \\
\text { age that } \\
\text { underwent } \\
\text { orthognathic } \\
\text { intervention: } \\
\text { BSSO, VRO, } \\
\text { LFI, and } \\
\text { BIMAX } \\
\text { (76 articles) }\end{array}$ & $\begin{array}{l}\text { BSSO, VRO, } \\
\text { LFI, and } \\
\text { BIMAX }\end{array}$ & $\begin{array}{l}\text { All observation } \\
\text { periods were } \\
\text { accepted }\end{array}$ & $\begin{array}{c}\text { Mandibular } \\
\text { movement } \\
\text { and } \\
\text { maximum } \\
\text { mouth } \\
\text { opening, } \\
\text { Palpation, } \\
\text { Imaging, } \\
\text { Bite } \\
\text { force,Quest } \\
\text { ionnaires }\end{array}$ & $\begin{array}{c}\text { Clinical } \\
\text { examination, } \\
\text { use of the } \\
\text { Helkimo } \\
\text { Index, the } \\
\text { RDC/TMD, } \\
\text { imaging } \\
\text { (including } \\
\text { CT, CBCT, } \\
\text { MRI, } \\
\text { panoramic } \\
\text { radiography, } \\
\text { tomography, } \\
\text { lateral } \\
\text { radiography, } \\
\text { transcranial } \\
\text { radiography, } \\
\text { and anterior- } \\
\text { posterior } \\
\text { radiography), } \\
\text { and patient } \\
\text { questionnaire } \\
\text { results }\end{array}$ \\
\hline $\begin{array}{l}\text { Nunes de } \\
\text { Lima et al., } \\
\text { (2018) (12) }\end{array}$ & $\begin{array}{c}\text { Evaluation of } \\
\text { condylar } \\
\text { resorption rates } \\
\text { after orthognathic } \\
\text { surgery in class II } \\
\text { and III } \\
\text { dentofacial } \\
\text { deformities: a } \\
\text { systematic review }\end{array}$ & $\begin{array}{c}\text { Systematic } \\
\text { Review }\end{array}$ & $\begin{array}{c}\text { MEDLINE (via } \\
\text { PubMed), } \\
\text { Embase and } \\
\text { Cochrane Library }\end{array}$ & $\begin{array}{c}\text { Individuals with } \\
\text { skeletal } \\
\text { dentofacial } \\
\text { deformities } \\
\text { (class II or class } \\
\text { III), } \\
\text { without } \\
\text { asymmetry that } \\
\text { underwent } \\
\text { orthognathic } \\
\text { surgery }\end{array}$ & $\begin{array}{l}\text { BSSO with or } \\
\text { without Le Fort } \\
1 \text { osteotomy }\end{array}$ & $\begin{array}{l}\text { Follow-up } \\
\text { period of } 12 \text { to } \\
16 \text { months }\end{array}$ & $\begin{array}{l}\text { Width and } \\
\text { height of } \\
\text { the } \\
\text { condyles or } \\
\text { condylar } \\
\text { volume }\end{array}$ & $\begin{array}{c}\mathrm{CT}, \\
\text { panoramic } \\
\text { radiography }\end{array}$ \\
\hline
\end{tabular}

BIMAX, bimaxillary osteotomy; BSSO, bilateral sagittal split osteotomy; CBCT, cone-beam computed tomography; CT, computed tomography; CR, condylar resorption; LFI, Le Fort I osteotomy; MRI. Magnetic resonance imaging; TMJ, temporomandibular joint. VRO, vertical ramus osteotomy; RDC/TMD, Research Diagnostic Criteria for Temporomandibular Disorders. 
Table 3: Results and Conclusions of the included studies ordered by date.

\begin{tabular}{|c|c|c|c|}
\hline Author (Year) & Title & Results & $\begin{array}{c}\text { Conclusions } \\
\end{array}$ \\
\hline $\begin{array}{l}\text { Bermell-Baviera } \\
\text { et al., (2016) (4) }\end{array}$ & $\begin{array}{l}\text { Effects of mandibular } \\
\text { advancement surgery } \\
\text { on the } \\
\text { temporomandibular } \\
\text { joint and muscular } \\
\text { and articular adaptive } \\
\text { changes - a systematic } \\
\text { review }\end{array}$ & $\begin{array}{l}\text { Idiopathic CR is in itself a clinical entity and that there is a } \\
\text { significant risk of postoperative degeneration. Progressive } \\
\text { postoperative CR is a multifactor process but follows an } \\
\text { established pattern. There is a higher incidence in patients with a } \\
\text { dolichofacial pattern and retrognathism and with preoperative } \\
\text { erosion, or condyle deformity, or both. Repositioning the condyle } \\
\text { reduces the risk of relapse and resorption. Risk factors for relapse } \\
\text { and CR are preoperative morphological characteristics of the } \\
\text { condyle and patients with a history of TMJ. }\end{array}$ & $\begin{array}{l}\text { Surgical MA with condyle repositioning is } \\
\text { associated with less TMJ, while this surgery } \\
\text { without repositioning carries a higher risk of } \\
\text { relapse. CR is a physiological process with a } \\
\text { multifactorial aetiology. It is accelerated } \\
\text { following MA surgery, but is not a } \\
\text { contraindication to this procedure. }\end{array}$ \\
\hline $\begin{array}{l}\text { Mousoulea et } \\
\text { al., (2016) (3) }\end{array}$ & $\begin{array}{l}\text { Condylar resorption in } \\
\text { orthognathic patients } \\
\text { after mandibular } \\
\text { bilateral sagittal split } \\
\text { osteotomy: a } \\
\text { systematic review }\end{array}$ & $\begin{array}{l}\text { Young female patients with mandibular deficiency and high } \\
\text { mandibular plane angle, submitted to surgical counterclockwise } \\
\text { rotation of mandibular segments were more prone to a higher risk } \\
\text { for CR after BSSO. }\end{array}$ & $\begin{array}{l}\text { Condylar resorption should be taken into } \\
\text { account as a potential postsurgical } \\
\text { complication after BSSO. However, its } \\
\text { incidence and quantification need } \\
\text { precautious interpretation owing to the low } \\
\text { level of evidence and the high heterogeneity } \\
\text { of studies. Additional high quality } \\
\text { prospective research assisted by 3-D imaging } \\
\text { technology is needed to allow more } \\
\text { definitive conclusions. }\end{array}$ \\
\hline $\begin{array}{l}\text { te Veldhuis et } \\
\text { al., (2017) (11) }\end{array}$ & $\begin{array}{l}\text { The effect of } \\
\text { orthognathic surgery } \\
\text { on the } \\
\text { temporomandibular } \\
\text { joint and oral } \\
\text { function: a systematic } \\
\text { review }\end{array}$ & $\begin{array}{l}\text { RELATIVE TO BSSO: } \\
\text { 1. Mandibular movement and maximum mouth } \\
\text { opening: Approximately two-thirds to three-quarters of } \\
\text { all patients in the BSSO and VRO groups showed no } \\
\text { difference in mandibular movements and maximum } \\
\text { mouth opening after a follow-up period of 1-2 years. } \\
\text { 2. Palpation:The majority of patients in the BSSO, VRO, } \\
\text { LFI, and BIMAX groups showed a decrease in post- } \\
\text { surgery pain on palpation. } \\
\text { 3. Bite force:For almost all patients in the different } \\
\text { surgical intervention groups, the maximum voluntary } \\
\text { bite force showed a general decrease in occlusal force } \\
\text { during the first few months after surgery, and then a } \\
\text { gradual increase in bite force towards the level of the } \\
\text { controls. } \\
\text { 4. Computed tomography: CBCT and CT:An inferior } \\
\text { and inward rotation of the condyle was found in the } \\
\text { BSSO and BIMAX groups. Remodeling, as defined by } \\
\text { a newly formed bony layer in the posterior part of the } \\
\text { condylar head, was reported for the VRO, BSSO, and } \\
\text { BIMAX groups. } \\
\text { Magnetic resonance imaging (MRI):For the BSSO } \\
\text { group, no change was found in articular disc position or } \\
\text { articular disc length on MRI. It is suggested that a } \\
\text { double contour-like demarcation line on MRI might } \\
\text { correspond to bone formation. Remodeling on the } \\
\text { superior surface of the condylar head was seen in some } \\
\text { joints on MRI. } \\
\text { Panoramic radiography:For the BSSO and LFI } \\
\text { groups, three articles described a greater vertical change } \\
\text { in the condyles, due to condylar resorption. In BSSO } \\
\text { remodeling was reported in 16\% and resorption of the } \\
\text { condylar head in 4\%. } \\
\text { 7. Tomography:A condylar anterior or posterior } \\
\text { displacement was seen in the BSSO group. } \\
\text { 8. Lateral radiography:In the BSSO group, no } \\
\text { significant effect on TMJ morphology and position was } \\
\text { seen. } \\
\text { Transcranial radiography:Changes in condylar } \\
\text { position and condylar remodeling and resorption were } \\
\text { seen in the BSSO group. }\end{array}$ & $\begin{array}{c}\text { The great variety of OS techniques, } \\
\text { examination techniques, diagnostic criteria, } \\
\text { and imaging techniques used in the articles } \\
\text { studied, as well as the quality of the study } \\
\text { designs, makes it difficult to compare studies } \\
\text { and to draw conclusions. However, looking } \\
\text { at the different aspects studied in general, it } \\
\text { can be stated that OS seems to have little or } \\
\text { no harmful effect on the TMJ and oral } \\
\text { function. }\end{array}$ \\
\hline
\end{tabular}


Table 3 cont.: Results and Conclusions of the included studies ordered by date.

\begin{tabular}{|c|c|c|c|}
\hline $\begin{array}{c}\text { Nunes de Lima } \\
\text { et al., } \\
\text { (2018) (12) }\end{array}$ & $\begin{array}{c}\text { Evaluation of } \\
\text { condylar resorption } \\
\text { rates after } \\
\text { orthognathic surgery } \\
\text { in class II and III } \\
\text { dentofacial } \\
\text { deformities: a } \\
\text { systematic review }\end{array}$ & $\begin{array}{c}\text { Four of the included studies reported the presence or absence of } \\
\text { postoperative relapse. The two studies measured the extent of } \\
\text { relapse, with values between } 2 \mathrm{~mm} \text { and } 6.4 \mathrm{~mm} .\end{array}$ & $\begin{array}{c}\text { The potential for progressive condylar } \\
\text { resorption and relapse represent a small } \\
\text { percentage of the included patients in this } \\
\text { study. The condylar resorption rate seems to } \\
\text { occur more in skeletal class II patients. }\end{array}$ \\
\end{tabular}

BIMAX, bimaxillary osteotomy; BSSO, bilateral sagittal split osteotomy; CBCT, cone-beam computed tomography; CT, computed tomography; CR, condylar resorption; LFI, Le Fort I osteotomy; MA, mandibular advancement; MRI, magnetic resonance imaging; TMJ, temporomandibular joint. VRO, vertical ramus osteotomy; OS, orthognathic surgery.

Table 4: Correlation between condylar remodeling and orthognathic surgery.

\begin{tabular}{|c|c|c|}
\hline $\begin{array}{c}\text { Author } \\
\text { year }\end{array}$ & Title & Condylar remodeling and orthognathic surgery \\
\hline $\begin{array}{c}\text { Bermell- } \\
\text { Baviera } \text { et al., } \\
(2016)(4)\end{array}$ & $\begin{array}{c}\text { Effects of mandibular advancement surgery on } \\
\text { the temporomandibular joint and muscular and } \\
\text { articular adaptive changes-a systematic review }\end{array}$ & $\begin{array}{c}\text { The authors conclude that postoperative condylar } \\
\text { resorption is a multifactor process, however it follows an } \\
\text { established pattern. The incidence of condylar } \\
\text { resorption is higher in patients with a dolichofacial pattern } \\
\text { and retrognathism and with preoperative erosion or } \\
\text { condyle deformity, or both. }\end{array}$ \\
\hline $\begin{array}{c}\text { Mousoulea } \text { et } \\
\text { al., (2016) (3) }\end{array}$ & $\begin{array}{c}\text { Condylar resorption in orthognathic patients } \\
\text { after mandibular bilateral sagittal split } \\
\text { osteotomy: a systematic review }\end{array}$ & $\begin{array}{c}\text { The authors refer that when BSSO was carried out alone or } \\
\text { in conjunction with other surgical procedures, it } \\
\text { resulted in condylar resorption, whose incidence ranged } \\
\text { from 1.4\% to 31\%. However, the range after a single-jaw } \\
\text { BSSO for mandibular advancement was between 3.6\% and } \\
10 \% .\end{array}$ \\
\hline $\begin{array}{c}\text { te Veldhuis } e t \\
\text { al., (2017) (11) }\end{array}$ & $\begin{array}{c}\text { The effect of orthognathic surgery on the } \\
\text { temporomandibular joint and oral function: a } \\
\text { systematic review }\end{array}$ & $\begin{array}{c}\text { The authors described a greater vertical change in the } \\
\text { condyles, due to condylar resorption, for the group that } \\
\text { underwent a BSSO. For this group, remodeling was } \\
\text { reported in 16\% and resorption of the condylar head in 4\%. }\end{array}$ \\
$\begin{array}{c}\text { Nunes de } \\
\text { (2018) (12) }\end{array}$ & $\begin{array}{c}\text { Evaluation of condylar resorption rates after } \\
\text { orthognathic surgery in class II and III } \\
\text { dentofacial deformities: a systematic review }\end{array}$ & $\begin{array}{c}\text { The potential for progressive condylar resorption and } \\
\text { relapse represent a small percentage of the included } \\
\text { patients in this study. The condylar resorption rate seems to } \\
\text { occur more in skeletal class II patients. }\end{array}$ \\
\hline
\end{tabular}

reason we chose a random effects model to estimate the global proportion value depicted in the forest plot (Figs. $2,3)(1,3-5,10-16)$.

\section{Discussion}

The incidence of condylar form alteration is an outcome reported in previous reviews $(2-5,11,17,18)$. However, the lack of meta-analysis concerning this subject was noted by the authors. Thus, we systematically evaluated and summarized evidence of data available with a statistical analysis from published SR.

The TMJ response to mandibular advancement ranged from adaptive, which included physiological bone remodeling, to irreversible complications (19).

The pathogenesis of condylar form alteration is not clearly identified, as this can be multifactorial. Therefore, it is not possible to recognize only one aetiological factor of TMJ changes. New unbalanced force vectors applied and absence of condylar adaptation may cause alterations on the condylar form. The internal rearrangement promotes disc displacement, with or without reduction, causing pressure on the articular surface during the rotation of the condyle, promoting the formation of TMD (12). One of the factors that may influence alteration of the condylar form is the magnitude of mandibular advancement and consequently the tension created from stretching the muscles as well as adjacent soft tissues. This tension may overcome the adaptive ability of the condyle creating compressive areas on the condylar head $(1,3,20)$.

The small prevalence of alteration of the condylar form $(\mathrm{OR}=0,04)$ may indicate that there is little influence on condylar alteration after mandibular advancement surgery $(3,4,10,11)$. 


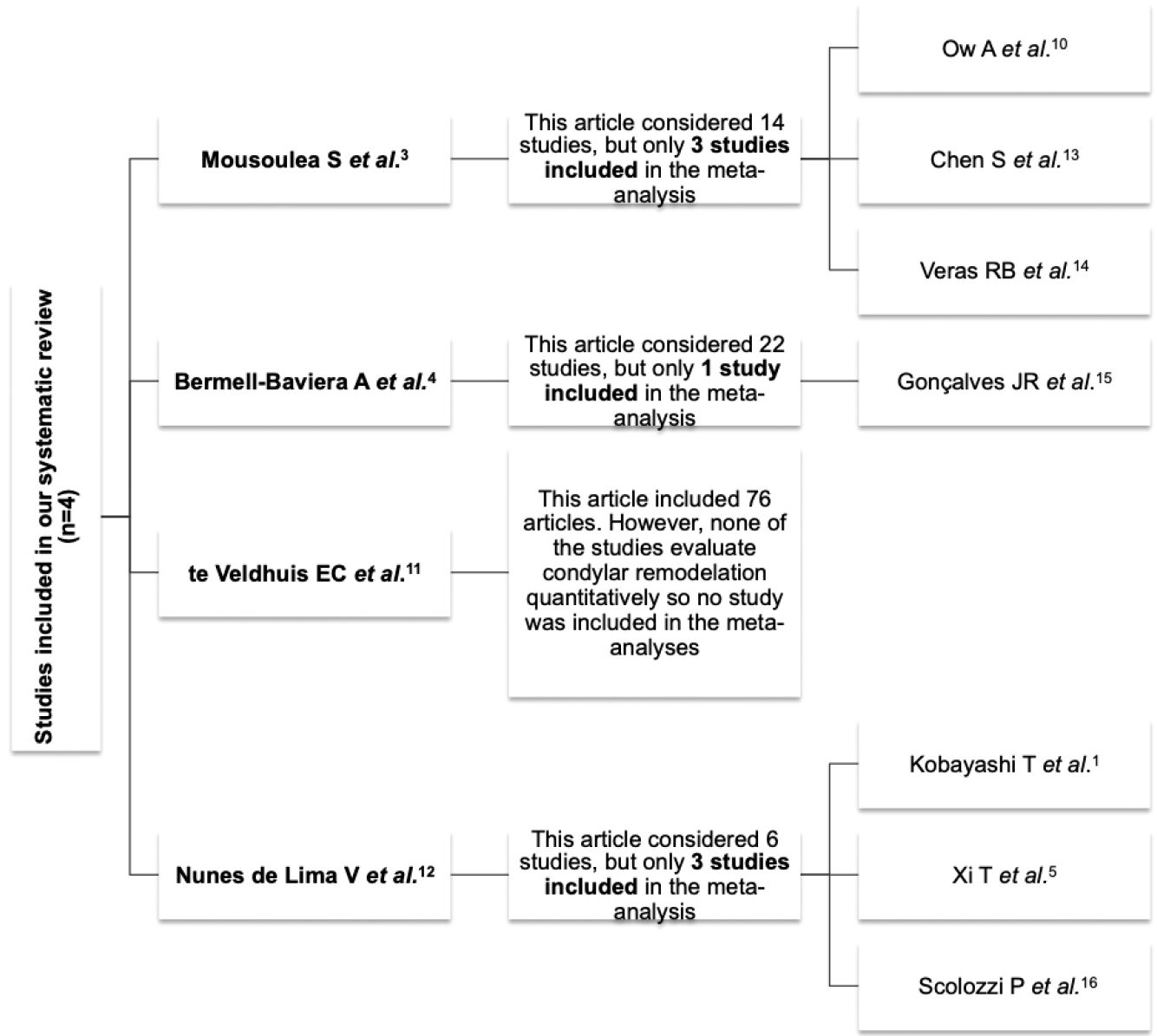

Fig. 2: Flow diagram of included studies in the meta-analysis.

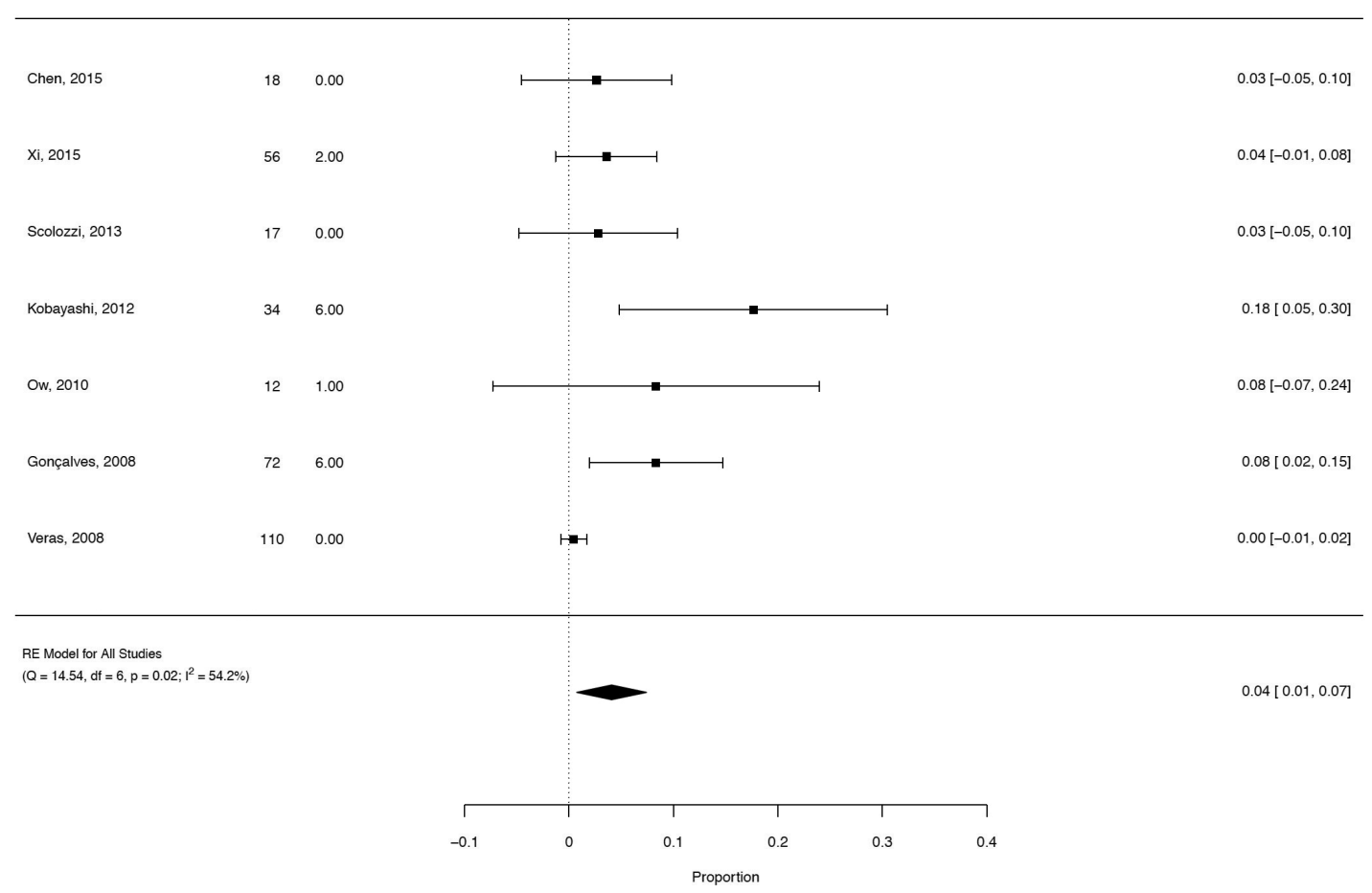

Fig. 3: Forest plot of Meta-analysis. 
The alteration of the condylar form is therefore more closely related to the surgical procedure in which there is counter clockwise rotation of the proximal mandibular segment, increasing the pressure on the less loaded surface of the anterior-superior condylar area (1). Deficit of blood supply appears to also have a role in condylar form alteration $(3,21)$.

Our research highlights the lack of quantity and quality of articles that assess the alteration of the condylar form on skeletal class II patients that have been submitted to orthognathic surgery. Of the 37 identified articles $75,7 \%$ were not relevant, $16.2 \%$ were ineligible by applying the inclusion and exclusion criteria and also due to a negative quality evaluation. In conclusion, only $8.1 \%$ were considered for the final analysis.

All selected studies showed that the alteration of the condylar form could be a consequence of BSSO with mandibular advancement surgery. The systematic review published by Mousoulea et al. in 2017 concluded that young female patients with mandibular deficiency and high mandibular plane angle, submitted to surgical counterclockwise rotation of mandibular segments, were more prone to alteration of the condylar form after BSSO (3).

Veldhuis et al., in 2017, identified condylar remodeling through cone-beam computed tomography (CBCT), computed tomography (TC), magnetic resonance imaging, panoramic radiography, lateral radiography and transcranial radiography. Panoramic radiography only identified condilar remodeling in patients that undergo BSSO. CBCT identified condilar remodeling in BSSO, vertical ramus osteotomy and bimaxillary osteotomy (11).

Another systematic review carried out by Bermell-Baviera et al., in 2016, shows that when idiopathic condylar resorption is present there is a significant risk of postoperative degeneration. Progressive postoperative alteration of the condylar form is a multifactor process but seems to follow an established pattern. Additionally, there is a higher incidence in patients with a dolichofacial pattern and retrognathism and with preoperative erosion, or condyle deformity, or both. Furthermore, repositioning of the condyle reduces the risk of relapse and alteration of its form. Preoperative morphological characteristics of the condyle and patients with a history of TMD are risk factors for relapse and alteration of the condylar form (4).

Of the 3 studies included, Bermell-Baviera et al. in 2016, Mousoulea et al. in 2016 and te Veldhuis et al. in 2017, all reported the use of CBCT to identify the alteration of the condylar form. As the design of the included studies were systematic reviews, some articles identified by them evaluated condylar resorption with 2-dimensional imaging techniques. Mousoules et al. concluded that additional high quality prospective research assisted by
3D- imaging technology is needed to allow more definitive conclusions $(3,4,10,11)$.

Even though 2-D imaging is commonly used, it cannot be considered the gold standard for evaluation of alteration of the condylar form. On the other hand, the magnification of 3-D imaging allows a superimposition and comparison of the condyles, enabling the correct assessment of condylar changes (resorption or remodeling) $(3,5,22)$.

All selected publications it is agreed that in the treatment of skeletal class II, after BSSO with mandibular advancement, alteration of the condylar form can occur (21). However, this finding should be treated with caution, as there is a considerable heterogeneity of the studies regarding this matter. The heterogeneity of these studies might be explained by differences in the study designs. Even though we used four systematic reviews, that included cohort studies (retrospective and prospective) $(3,4,11)$.

The types of surgical interventions included in the four articles are not homogeneous: Bermell-Baviera et al., evaluate only studies with BSSO mandibular advancement surgery, whereas the other two studies, included articles where BSSO surgery was performed with other surgical procedures, such as Le Fort I (4).

A qualitative assessment was performed using AMSTAR 2 analysis, which provide methodological quality of included articles.

In this review we defined very strict inclusion and exclusion criteria, which may influence the results obtained. The heterogeneity found in the included studies is also a limitation.

To conduct this overview, the authors only include systematic reviews, excluding randomized and non-randomized controlled trials and cohort studies. Therefore, our review sample was low because of methological problems in the assessed papers. Most studies showed no randomization of their sample, as it is difficult to randomize a surgical procedure.

Another important limitation of the quality assessment was the lack of methods for quantifying the alteration of the condylar. Future study designs should randomize their samples from the beginning fostering their evidence, as is mentioned on the CONSORT (Consolidated Standards of Reporting Trials) guidelines. However, for ethical reasons, randomized clinical trial designs involving surgery are limited.

More studies on this topic are needed, particularly with more high-quality research.

\section{Conclusions}

-Implications for clinical practice

Base on the meta-analysis, the alteration of the condylar form may be a consequence of BSSO with mandibular advancement surgery. Due to the aforementioned limita- 
tions of the methodology, these results should be taken carefully. Additional high quality prospective research assisted by $3 \mathrm{D}$-imaging technology is needed to allow more definite conclusions.

-Implications for Research

These findings clearly demonstrate the necessity of further randomized controlled trials in order to evaluate not just the condylar resorption presence but also to quantify and differentiate the changes in the condyle (remodeling and resorption).

\section{References}

1. Kobayashi T, Izumi N, Kojima T, Sakagami N, Saito I, Saito C. Progressive condylar resorption after mandibular advancement. Br J Oral Maxillofac Surg. 2012;50:176-80.

2. Catherine Z, Breton P, Bouletreau P. Condylar resorption after orthognathic surgery: A systematic review. Rev Stomatol Chir Maxillofac Chir Orale. 2016;117:3-10.

3. Mousoulea S, Kloukos D, Sampaziotis D, Vogiatzi T, Eliades T. Condylar resorption in orthognathic patients after mandibular bilateral sagittal split osteotomy: a systematic review. Eur J Orthod. 2017;39:294-309.

4. Bermell-Baviera A, Bellot-Arcis C, Montiel-Company JM, Almerich-Silla JM. Effects of mandibular advancement surgery on the temporomandibular joint and muscular and articular adaptive changes - a systematic review. Int J Oral Maxillofac Surg. 2016;45:545-52.

5. Xi T, Schreurs R, van Loon B, Koning M, Bergé S, Hoppenreijs et al. 3D analysis of condylar remodelling and skeletal relapse following bilateral sagittal split advancement osteotomies. J Craniomaxillofacial Surg. 2015;43:462-8.

6. Viechtbauer W. Conducting Meta-Analyses in R with the metafor Package. J Stat Softw. 2010;36:1-48.

7. Hwang S, Haers P, Sailer H. The role of a posteriorly inclined condylar neck in condylar resorption after orthognathic surgery. Journal of Cranio-Maxillofacial Surgery. 2000;28:85-90.

8. Hwang S, Haers P, Zimmermann A, Oechslin C, Seifert B, Sailer H. Surgical risk factors for condylar resorption after orthognatic surgery. Oral Surg Oral Med Oral Pathol Oral Radiol Endod. 2000;89:542-552. 9. Eggensperger N, Smolka K, Luder J, Iizuka T. Short- and longterm skeletal relapse after mandibular advancement surgery. Int J Oral Maxillofac Surg. 2006;35:36-42.

10. Ow A, Cheung LK. Bilateral sagittal split osteotomies versus mandibular distraction osteogenesis: A prospective clinical trial comparing inferior alveolar nerve function and complications. Int J Oral Maxillofac Surg. 2010;39:756-60.

11. te Veldhuis EC, te Veldhuis AH, Bramer WM, Wolvius EB, Koudstaal MJ. The effect of orthognathic surgery on the temporomandibular joint and oral function: a systematic review. Int J Oral Maxillofac Surg. 2017;46:554-63.

12. Nunes de Lima V, Faverani L, Júnior J, Palmieri C, Filho O, Pe1lizzer E. Evaluation of condylar resorption rates after orthognathic surery in class II and III dentofacial deformities: A systematic review. Journal of Cranio-Maxillo-Facial Surgery. 2018;46:668-673.

13. Chen S, Liu XJ, Li ZL, Liang C, Wang XX, Fu KY, et al. Three-dimensional evaluation of condylar morphology remodeling after orthognathic surgery in mandibular retrognathism by cone-beam computed tomography. Beijing Da Xue Xue Bao Yi Xue Ban. 2015;47:703-7. 14. Veras RB, Kriwalsky MS, Hoffmann S, Maurer P, Schubert J. Functional and radiographic long-term results after bad split in orthognathic surgery. Int J Oral Maxillofac Surg. 2008;37:606-11.

15. Gonçalves JR, Cassano DS, Wolford LM, Santos-Pinto A, Márquez IM. Postsurgical stability of counterclockwise maxillomandibular advancement surgery: affect of articular disc repositioning.J Oral Maxillofac Surg. 2008;66:724-38.

16. Scolozzi P, Momjian A, Courvoisier DS, Kiliaridis S. Evaluation of condylar morphology following orthognathic surgery on digital pa- noramic radiographs. Could methodology influence the range of "normality" in condylar changes? Dentomaxillofacial Radiol. 2013;42:1-5. 17. Miao Z, Wang X-D, Mao L-X, Xia YH, Yuan LJ, Cai M, et al. Influence of temporomandibular joint disc displacement on mandibular advancement in patients without pre-treatment condylar resorption. Int J Oral Maxillofac Surg. 2017;46:328-36.

18. Sebastiani AM, Baratto-Filho F, Bonotto D, Kluppel LE, Rebellato NL, Costa DJ, et al. Influence of orthognathic surgery for symptoms of temporomandibular dysfunction. Oral Surg Oral Med Oral Pathol Oral Radiol. 2016;121:119-25.

19. Valladares-Neto J, Cevidanes LH, Rocha WC, Almeida G de A, Paiva JB, Rino-Neto J. TMJ response to mandibular advancement surgery: an overview of risk factors. J Appl Oral Sci. 2014;22:2-14.

20. Goncalves JR, Wolford LM, Cassano DS, da Porciuncula G, Paniagua B, Cevidanes LH. Temporomandibular joint condylar changes following maxillomandibular advancement and articular disc repositioning. J Oral Maxillofac Surg. 2013;71:1759.e1-15.

21. Chen S, Lei J, Wang X, Fu K-Y, Farzad P, Yi B. Short- and longterm changes of condylar position after bilateral sagittal split ramus osteotomy for mandibular advancement in combination with Le Fort I osteotomy evaluated by cone-beam computed tomography. J Oral Maxillofac Surg. 2013;71:1956-66.

22. Xi T, van Loon B, Fudalej P, Berge S, Swennen G, Maal T. Validation of a novel semi-automated method for three-dimensional surface rendering of condyles using cone beam computed tomography data. Int J Oral Maxillofac Surg. 2013;42:1023-9.

\section{Acknowledgements}

The authors would like to thank Dr. Helena Donato for her contribution to the manuscript.

\section{Funding}

This research did not receive any specific grant from funding agencies in the public, commercial, or not-for-profit sectors.

\section{Conflict of interest}

Non declared. 